
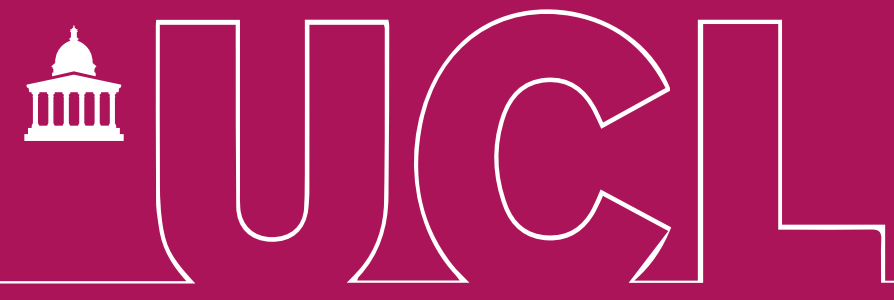

\title{
LOST IN TRANSLATION?
}

\section{AN ASSESSMENT OF THE SDGS AS A BASIS FOR PRIVATE SECTOR ACTION:}

A case study of palm oil

K. Tracey Campbell

Working paper 002-2019/10

(a) Institute for 


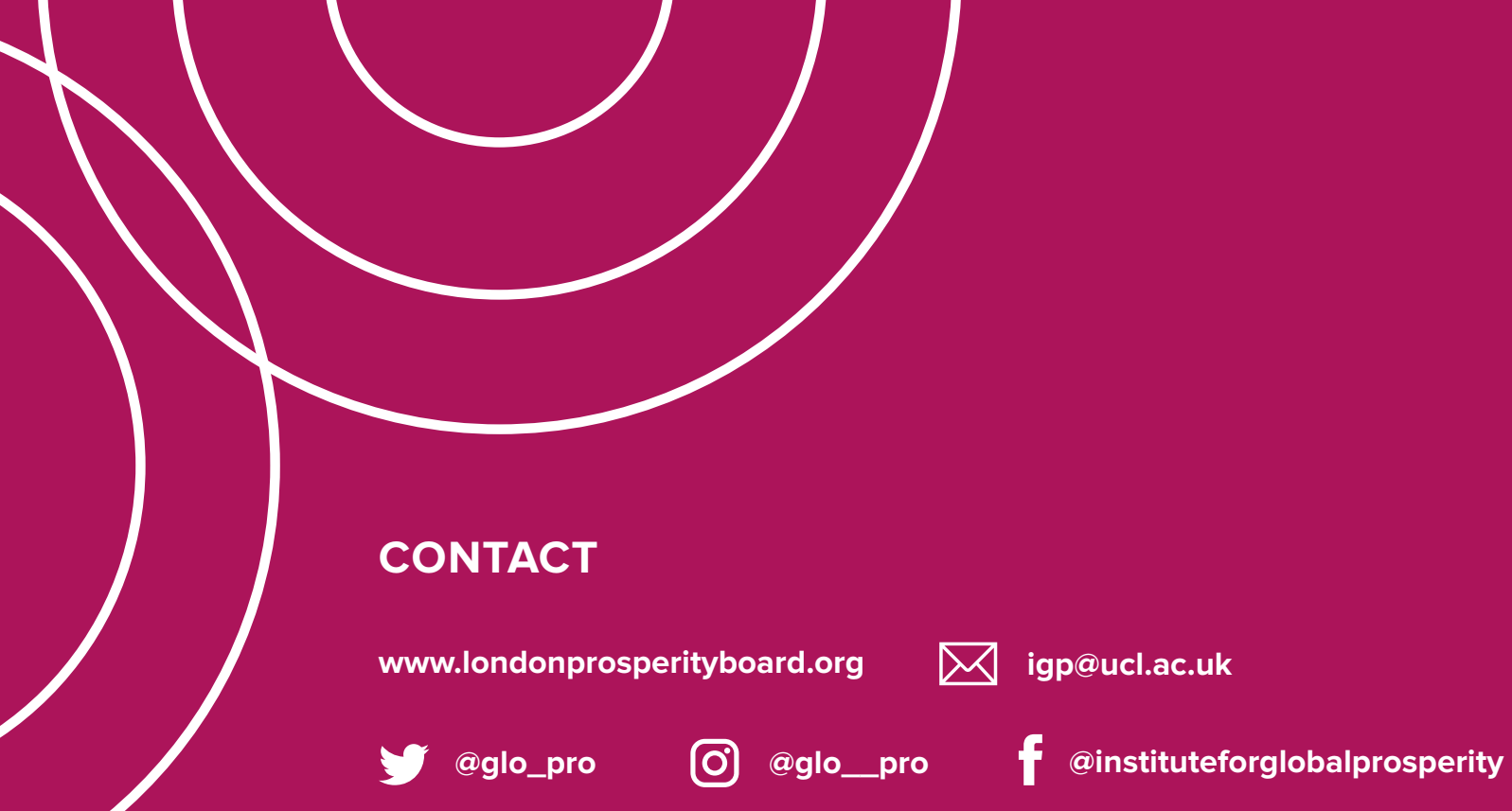




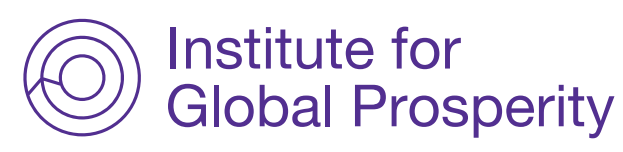

The IGP's vision is to help build a prosperous, sustainable, global future, underpinned by the principles of fairness and justice, and allied to a realistic, long-term vision of humanity's place in the world. The IGP undertakes pioneering research that seeks to dramatically improve the quality of life for this and future generations. Its strength lies in the way it allies intellectual creativity to effective collaboration and policy development. Of particular importance to the IGP's approach is the way in which it integrates non-academic expertise into its knowledge generation by engaging with decision-makers, business, civil society, and local communities.

For further information please contact: igp@ucl.ac.uk

To be cited as: Campbell K. T. (2019) Lost in Translation? An assessment of the SDGs as a basis for private sector action: A case study of palm oil, London: Institute for Global Prosperity.

DOI: 10.14324/000.wp.10081005 


\section{LOST IN TRANSLATION? \\ AN ASSESSMENT OF THE SDGS AS A BASIS FOR PRIVATE SECTOR ACTION: \\ A CASE STUDY OF PALM OIL}

K. Tracey Campbell 


\section{ABSTRACT}

This desk study forms part of the preparatory work for a PhD on investor engagement with companies on corporate responsibility issues, taken as those framed by the Sustainable Development Goals (SDGs). The SDGs outline ambitions widely accepted as improving the prosperity of populations in both developed and developing countries. Looking at these goals in greater detail however highlights the difficulty in matching the government-designed indicators of success to points of articulation with responsible corporate behaviour. This study looks at one example of an agricultural supply chain - palm oil - to illustrate the challenges involved in engaging a commercial industry with the SDGs using recent academic sources. It concludes that while at the icon level the goals do indicate targets and considerations for new or amended business models, they are too often short on detail with indicators that are descriptive rather than prescriptive. Therefore, private sector engagement will have to be flanked by the development (or reinforcement) of other standard-setting institutions to endorse that these changes are both desirable and credible. This will involve the co-operation of a wide array of stakeholders which will be the subject of further IGP research.

\section{KEYWORDS}

Sustainable Development Goals, private sector, corporate responsibility, stakeholders, palm oil

\section{CONTACT}

E-mail : tracey.campbell.16@ucl.ac.uk

Address : Tracey Campbell, c/o Institute for Global Prosperity, Maple House, 149 Tottenham Court Rd, London W1T 7NF 


\section{TABLE OF CONTENTS}

Abstract
$\mathbf{5}$

Keyword

Contact
$\mathbf{5}$

$\begin{array}{ll}\text { Introduction } & 7\end{array}$

The Sustainable Development Goals $\quad 8$

Goal 1: End poverty in all its forms everywhere 9

Goal 2: End hunger, achieve food security and improved nutrition and promote

sustainable agriculture 10

Goal 3: Ensure healthy lives and promote well-being for all at all ages 12

Goal 5: Achieve gender equality and empower all women and girls 12

Goal 6: Secure availability and sustainable management of water and sanitation for all 13

Goal 7: Secure access to affordable, reliable, sustainable and modern energy for all 14

Goal 8: Sustained, inclusive and sustainable economic growth, full and productive employment and decent work for all

Goal 10: Reduce inequality within and among countries 17

Goal 12: Secure sustainable consumption and production patterns 18

Goal 13: take urgent action to combat climate change and its impacts 19

Goal 15: protect, restore and promote sustainable use of terrestrial ecosystems, sustainably managed forests, combat desertification and hold and reverse land degradation and hauled biodiversity loss.

Goal 16: promote peaceful and inclusive societies for sustainable development, provide access to justice for all, and build effective, accountable and inclusive institutions at all levels.

Conclusions

Bibliography 


\section{INTRODUCTION}

At the UN Millennium Summit in 2000, 189 countries signed up to a ground-breaking agreement to deliver eight key goals across the world by 2015 (the United Nations Millennium Declaration). These Millennium Development Goals (MDGs) were focused on widespread development of human capital in developing countries, with a clear skew towards public health and education. Subsequent criticism included a perception that the recipient countries were the least consulted in the design of the project. At the conclusion of the period several of the key metrics showed improvement- notably the share of the population living below the poverty line- but success varied greatly by nation and most were dependent upon cash aid transfers from developed to developing countries and trickle-down development economics. Few of the initiatives involved changes in pre-existing business models or engagement with the private sector. Nonetheless the UN sought to continue the momentum to synchronise international action and engaged in extensive consultation to define new ambitions which would incorporate environmental and social justice concerns and apply to all countries, both developed and developing.

The succeeding UN agreement 'Transforming our World: the 2030 Agenda for Sustainable Development' was signed by 193 countries in September 2015 and included a list of seventeen ambitions now more widely known as the Sustainable Development Goals (SDGs). The issues they raise are wide-ranging and interlinked and cover many of the issues that contribute to definitions of prosperity: access to services for health and education; the right to low pollution levels; protection from violence and promotes a less damaging relationship with the environment (which covers climate change and biological assets). It is also emphasised explicitly that efforts to achieve these goals necessitate cooperation between many actors: the government, NGOs, sources of finance and the private sector. Despite this insistence, the many metrics attached to each goal have been written in a way that makes articulation with commercial entities in business or the capital markets clumsy at best.

The fourth anniversary of the UN publication of the SDGs now approaches and already the icons for individual goals appear liberally scattered across NGO documents, company annual reports, government policy documents and investor websites as indicators of support. It is the intention of this paper to investigate this issue further and see whether the ambitions of the SDGs can link directly into strategies for greater corporate responsibility in the private sector. To provide a grounded illustration of the complexities involved a tropical agricultural crop was selected: palm oil. A literature search was conducted for the palm oil industry using the terms mentioned in each goal title (plus synonyms) and the resulting papers searched for evidence and insights as to current practice. By design, no private sector practitioners or NGOs were consulted at this stage but will be covered in a subsequent paper. All of the academic evidence for the social and environmental challenges involved comes from literature published recently (predominantly since 2010). 


\section{THE SUSTAINABLE DEVELOPMENT GOALS}

Although the colourful seventeen icon diagram is widely publicised, the label attached to each is a contraction of the section titles in the UN 2015 report. Thus Goal 2 is labelled 'No Hunger' but has a full title of 'End hunger, achieve food security and improved nutrition and promote sustainable agriculture'. What is clear even from the abbreviated labels is that several SDGs have aims that are in tension with each other. Using the palm oil example, palm oil biodiesel expansion is a good development towards modern energy (SDG 7), its nutritional gains are positive (SDG 2) and the economic growth it brings is to be welcomed (SDG1). However, the forest clearance so often associated with it is negative for both biodiversity (SDG 15) and carbon release (SDG13), the pollution from the mills that extract the oil unwelcome (SDG6) and uneven sharing of the economic gains from its production demands careful scrutiny (SDGs 1 and 10).

Under the expanded title for each goal there is even greater complexity in the array of sub-elements to each goal which outline more detailed targets and the indicators by which success will be measured. In this analysis, the targets expressed in more detail for SDG 1 for example are identified as 1.1 and 1.2, and below each target the indicators by which progress will be measured are labelled 1.1.1 or 1.2.1. The indicators took longer to define and were only published in July 2017 (as UN resolution A/RES/71/313) and have been amended twice since then. The current 2019 version includes 244 indicators arranged in three tiers, which represent a qualitative classification: Tier 1 indicators have an existing established methodology and data that are already widely available; Tier 2 indicators have an existing established methodology but data are not easily available and Tier 3 indicators do not yet have an internationally agreed methodology and are still being worked on. To clarify a frequent confusion, because the 244 total indicators mentioned include six duplicate entries allocated under different goals and three triplicate entries, the total number of data points requested from each government is 232 . The most current data for any country that has elected to submit a response can be found on the UN website on https://unstats.un.org/sdgs/indicators/database/ .

It should however be noted that the term 'data point' is perhaps generous: the metrics vary greatly from longstanding public health quantitative measures such as SDG 3.1.1 'maternal mortality ratio' to new data which may be extremely hard to gather in any credible fashion, such as 15.7.1 which seeks identification of the "proportion of traded wildlife that was poached or illegally trafficked'. Other 'metrics' are more of a 'tick box' exercise, such as 12.1 .1 'does the country have a sustainable consumption and production action plan?' without any indication as to what this plan should incorporate. In almost every case data is aggregated at the national level into a single line entry which ignores the importance of alternative relevant location-based issues (such as watershed or ecosystem management). Further, the preference for ratios, such as 15.1 .1 'forest area as a proportion of total land area' means that the absolute significance of the forest cover in existence at a global scale cannot be constructed from the data submitted, and there is little value in knowing 
that low forest cover countries have increased this proportion over time while major forested nations, such as Brazil may have reduced it. There is therefore a missing element of judgement as to the potential for impact of the style of indicator chosen. It also remains the case that even if every individual country shows some improvement in the indicators selected, collectively the impact may not be sufficient to make a meaningful change at global level.

The format of this report is to present the issues and contradictions in each goal that was found to have relevance for the behaviour of the commercial palm oil industry. The goals are discussed in the sequence set out by the UN to make them easy to find but there is not in this arrangement a particular logical sequence or prioritisation of issues, other than the fact that MDG issues come early in the list. In the interests of space management some SDGs have been excluded such as education, sustainable cities and marine life. It then discusses which - if any - of the indicators requested provide guidance or structure that can be adopted into corporate responsibility initiatives.

\section{GOAL 1: END POVERTY IN ALL ITS FORMS EVERYWHERE}

Several of the analyses of the Millennium Development Goals highlighted the fact that economic growth for an economy can deliver poverty reductions in line with traditional trickledown development economics. The combination of climate and terrain which provide the capability to produce a valuable primary agricultural resource such as palm oil can be part of an export-led economic success story. The key countries involved in this crop are Malaysia and Indonesia who together produce over $80 \%$ of the world's palm oil (FAOSTAT). In national statistics both countries show average incomes well above the absolute poverty measures indicated in SDG 1.1 of \$1.25 per day: absolute GNI per capita recorded by the World Bank gives a figure for Malaysia of \$10,460 in 2018 and for Indonesia $\$ 3,840$. Employment in the industry is also significant: Cahyadi and Waibel in their 2013 Indonesian study suggest the involvement of $3.5 \mathrm{~m}$ labourers ( $9 \%$ of the agricultural sector) and Deros et $a$ l in their 2016 work suggest a figure of $0.5 \mathrm{~m}$ people in Malaysia (although the technicalities of plantation employment status are discussed further under SDG8). Exports of palm oil contribute significant foreign exchange earnings to these economies: World Integrated Trade Statistics indicate 2017 levels of \$13.8bn for Indonesia and $\$ 7.8 \mathrm{bn}$ for Malaysia. Academic research produced by industry bodies - as would be expected - reflects this narrative: for example, Basiron (2007), writing on behalf of the Malaysian Palm Oil Council states that

"involvement in cultivation or downstream activities has uplifted the quality of life of people...this has helped alleviate poverty among landless farmers in Malaysia" (p289).

However, the use of aggregate statistics in the indicator masks considerable inequalities: the most recent World Bank Statistics show a GINI coefficient of 41 for Malaysia (in 2015) and 38.1 for Indonesia (for 2017). These need to be compared to Norway's score of 25 - seen as one of the world's most equal economies - indicating an extremely unequal allocation of this wealth. Adverse incorporation into the economy is a recurrent theme in palm oil studies and this issue is discussed more in SDG 5 (gender empowerment) and SDG 8 (decent work).

A key prosperity indicator: the security of livelihood is identified in SDG 1.4.2 which asks for 'the proportion of the total population with secure tenure rights to land, with legally recognised documentation and who perceive their rights to land as secure, measured by gender and type of tenure'. From academic studies, the transaction between small shareholder farmers and the plantation management can appear entirely acceptable on 
paper: Bisonette's 2013 Indonesian study showed that the smallholder typically gives up 5-7 hectares of land to the plantation in return for 2 hectares of seedling-planted oil palm. However, using qualitative interviews in Indonesia, he showed that the judicial priority given to the core estate ('Inti') plantation taking over land means that local smallholders are relieved of their land with little power to influence when they will receive the small oil palm ('plasma') plantations in return or even where those plots will be located. Payment terms for the early high investment costs of the plasma such as fertiliser are all plantation-determined: often opaque calculations which can lead to financial hardship requiring the outright sale of the plasma plot, often back to the plantation. Libraswulan (2014) suggests a figure of debt capacity of $\$ 1,500$ needed for a 2-hectare plasma plot which was, based on her research, charged at $15.5 \%$ interest by the plantation making the loan. These compounding financial burdens were often inadequately understood by farmers who had signed the contracts, could result in cash flow deficiencies which could only be met through the sale of the plot itself. Bissonette notes:

"according to village level information corroborated by interviews with plantation officials... $50 \%$ of the original landholders had sold their plots by 2011" (p499).

Thus contracts, even if clear on paper, may not be clearly understood and not equitably enforced on the ground, undermining the resilience of smallscale farmers in the plantation areas. The combined dependence on the plantation described here for both land and capital cries out for improved alternative agricultural finance channels, which could be provided by the private sector.

The importance of infrastructure in improving smallholder income resilience is also relevant here. Cahyadi and Waibel (2013) noted the asymmetric power dynamics in smallholder contracts were exacerbated if the area contains only one mill which can abuse its market dominance. Using a multivariate regression analysis, they showed that contracted smallholders in possession of larger land assets (an average of 4.59 ha) did benefit from taking up contract arrangements for their output. However, as controllers of the channel to market, plantations appeared to ignore plot owners possessing less than 2 hectares who were therefore left vulnerable to ad hoc processing prices and opportunities. A Feintrenie (2010) study noted that the "fairness" of contract and price arrangements was greatly improved through increased competition between mill owners: increased mill density reduces monopsony concerns and increases the reach of oil palm opportunities given the 48 hour limit on the travel of viable fresh fruit bunches (FFBs) to the mill. Distributed processing investments could therefore encourage more positive development outcomes in new developments but the loss of scale economies may require offsetting government support.

\section{GOAL 2: END HUNGER, ACHIEVE FOOD SECURITY AND IMPROVED NUTRITION AND PROMOTE SUSTAINABLE AGRICULTURE}

This SDG incorporates many diverse data points which, if provided by national statistics authorities, will provide a broad and deep update on rural livelihoods. SDG 2.3.1 requests information about labour productivity by type of farming and SDG 2.4.1 asks for the proportion of the national agricultural area which is under productive and sustainable agriculture to which corporations can contribute data. However 'sustainability' is left undefined here and elsewhere, which is discussed further under SDG12.

It is on the issue of the prevalence of food insecurity (SDG 2.1.2) that palm oil makes a recognisable contribution to this goal: World Growth's 2010 report 'Palm oil and food security: the impediment of land supply' states clearly: 
"Palm oil has done more to enhance food security than any of the other vegetable oils and many other crops... Moreover, palm oil's clear and persistent price advantage makes it highly attractive for the many households in the developing world who rely on it as a food staple. It makes no sense to willingly abandon these advantages" (p14).

Indeed, the Malaysian Palm Oil Council emphasises that palm oil is the most attractive of the vegetable oil crops: highest oil yield per hectare, per manhour and per weight of plant collected (Basiron 2007). These qualities are endorsed by Nesadurai (2013): palm oil is a "cheap but nutritious food staple that is also the most efficient oilseed to date measured in terms of oil yield and land utilisation" (Nesadurai 2013: 508), although she adds 'palm oil's claimed advantages are undermined by its role in deforestation, global warming, biodiversity loss and social conflict'. Lam et al (2009) note that a high share of saturated fatty acids in palm oil was formerly thought to make the product unhealthy but the Codex Alimentarius of the WHO now includes it in its list of acceptable ingredients. Fry and Fitton (2013) note two health aspects which favour this oil: firstly, its high melting point (ie it is solid at room temperature) means that it offers particular organoleptic qualities while avoiding the need for hydrogenation required by other oils (a process now seen as a source of unhealthy trans fats); and secondly, the oil incorporates useful precursors to vitamin A - carotenoids- which can offset deficiencies occurring elsewhere in the diet. Lam et al (2009) also comment on the presence of tocopherols and tocotrienols - Vitamin E precursorsin the product which add further micronutrients to the diet. All of these attributes should contribute to this SDG's focus on malnutrition and stunting in children (metrics SDG 2.1.1, SDG2.2.1 and SDG2.2.2), which is recognised by Euler's 2017 econometric study as being prevalent in Indonesia.
Offsetting these advantages, the expansion of large palm oil monoculture plantations carries the risk of crowding out a variety of other food sources. Nesadurai (2013) notes that the transfer of communal land to plantation owners also excludes local and indigenous people from foraging for subsistence among the prior wild plants in those areas to diversify their diet. Certainly, when hectares of previously mixed smallholding are given up to the plantation, the ability of a smallholder to feed their family reliably is diminished until the palm oil cash starts to arrive which may be 2-3 years later. Research by Lam et al (2009) suggests that a transition planting mix (including sugar cane, pineapple, bananas) is possible in the early unproductive years of new palm oil plantings to offset this gap in production and that livestock can be combined with palm oil at an intensity of one cow per hectare. Plantation management guidelines to encourage such diversification could improve local food security concerns. Added benefits of the livestock scheme include reduced weeding, better soil structure and reduced fertiliser use, as animal dung is available on site. Increased monoculture production, even if local hires are paid in cash, generates an increasing dependence on the availability of food markets to provide households with their nourishment, increasing vulnerability to price or supply shocks (an indicator sought in SDG 2.1.2).

This SDG also seeks data on the income of smallscale food producers (SDG2.3.2). While much criticism of the palm oil industry focuses on plantation owners and large-scale land clearances it is important to recognise the share of the industry still supplied by smallholders: Euler's (2017) research in Indonesia suggests that $36 \%$ of national palm oil production arises from smallholder farms so the local impact on cash incomes in communities is significant. Malaysia's share of smallholders is indicated around 37\% (Hamilton-Hart 2014). Corporations willing to open their processing facilities to engage with local smallholders could contribute to providing resilient local livelihoods, provided they avoid the contract abuse mentioned above. 
It is also worth spending a moment on the biodiversity of the oil palm crop itself as this SDG incorporates issues of preserving the agricultural gene pool as target 2.5. Basiron (2007) notes that in Malaysia. "Due to a very narrow genetic base of only four mother palms used historically in the propagation of palm in Malaysia, the oil is uniform in its characteristics, with a very narrow range in physical parameters". More recent nursery collections have been expanded using other West African varieties to improve yields, reduce mature palm tree height for easier harvesting and increase the carotenoid content of the oil. These interventions have been achieved through standard breeding practices and existing high yields are a result of extensive hybrid cross-breeding of tenera and dura species of the oil palm, thus retaining genetic diversity. However, these cross-breeds do not always breed 'true' and so it has been in the increasing interest of plantation owners to develop clonal populations of high yielding plants. Corley and Tinker (2003) discuss the complexity of this process and the need for substantial investment in laboratory expertise for tissue culture, requiring special nutrient solutions and mastery of difficult, time-consuming techniques. This process started in the 1960s and produced the first clonal plantation in Malaysia in 1977, although the process has been beset with difficulties. Even though techniques have improved, clonal production remains ten times more costly than normal seedlings, putting them out of the reach of smallholders while employed in large scale plantations. This raises the concern of a reduction in the gene pool variety within the commercial oil palm sector which could introduce the risk of the sort of vulnerability to disease now faced by the producers of vegetatively-produced Cavendish bananas.

\section{GOAL 3: ENSURE HEALTHY LIVES AND PROMOTE WELL-BEING FOR ALL AT ALL AGES}

The metrics of choice for this SDG focus upon mortality rates, the delivery of healthcare services, fertility and family planning and the incidence of key diseases, which are a focus of government or third sector organisations. However, corporations may make a contribution towards providing healthcare insurance (SDG3.8.2) or offer health services to employees such as vaccinations (SDG3.b.1) as part of their terms of contract. As an industry, palm oil's most direct impact on this ambition is on SDG3.9.1 "mortality rate attributed to household or ambient air pollution" as land clearance through burning is common practice. Othman (2003) notes the annual August to October persistent period of 'haze' -fine particulates in the atmosphere- which damage health, fishing and farming. This is despite increased environmental regulations, particularly in Peninsular Malaysia, which seem to be absent or ignored in areas such as Riau province, Sumatra and Central Kalimantan in Indonesia and the island regions of Malaysia. The institutional lack of enforcement means that this undesirable air pollution is likely to remain a feature of the region unless reduced through voluntary codes of practice. Libraswulan (2014) observes that even with RSPO certification at the plantation level which specifically discourages burning, the process still goes ahead annually. Where burning tracts can be associated with specific owners, using GPS technology as evidence, there is scope for 'name and shame' publicity by NGOs to act as a lever on corporate behaviour, and without this contract terms to third party suppliers by large corporate buyers are unlikely to prove an effective deterrent. The incidence of the problem is all that is noted by this SDG, the solution remains something that must be negotiated between stakeholders.

\section{GOAL 5: ACHIEVE GENDER EQUALITY AND EMPOWER ALL WOMEN AND GIRLS}

This seems on the surface a straightforward SDG but it splits between asking for records of poor treatment of women and records of women's status. Six of the fourteen indicators for this goal relate to child marriage, sexual violence (including female genital mutilation) plus a further two on access to family planning. Indicator 5.1.1 asks if there is a legal framework for recognising sexual discrimination, but in all of these instances, there is no request for any 
proof of legal redress for any of these grievances. SDG 5.5.1 asks for the proportion of seats held by women in local and national government, which is clearly an issue of local and national politics. Only with SDG 5.5.2 which asks for the proportion of women in managerial positions can the private sector make a clear contribution through workplace action.

A further key metric in this section, probably more relevant for developing markets, relates to whether women can own or take tenancy of agricultural land (5.a.1 (a) and 5.a.2). This is partly a reiteration of SDG 1.4.2 where tenancies are to be reported by gender but with the added element in this case that women's ownership be recognised in local law. In terms of supply of goods and services, businesses could help here in recognising contracts with women, even using positive discrimination, in order to build a pool of female entrepreneurs. At the other end of the spectrum, in their ethnography White and White (2012), working in Indonesia, highlight how the expansion of corporate plantation and accompanying smallholder contract farming has undermined the position of indigenous Dayak women, as contract counterparties have dealt only with traditional patriarchal leaders in the community. In the area of Sanggau where they worked, even the act of titling transferred communal property specifically to male farmers, who transacted an exchange with the plantation as a long lease. Without being named on documents relating to land, women lost access to credit since they had no recognisable collateral to offer. Only a few female farmers in this study were able to establish any direct titling of land. The same research also notes that despite this exclusion, women have inherited the maintenance obligations on the smallholder oil palm plots they don't own since this does not qualify as 'men's work' (ie heavy labour for cash).

Although SDG 5.4.1 'the proportion of time spent on unpaid domestic and care work, by sex, age and location' does ask for more information on how women's time is spent in the home, there is no recognition of how much agricultural labour women do as part of a family group for which they are not paid directly. White and White also noted that berondol (loose palm fruit) gleaning was gendered work, left to women and children and-rather unusually- paid for directly in cash per sack. This involves picking up scattered fruits either from the roadside or within the plantations. Even though the fruit would otherwise be left to rot, the authors indicate that plantation authorities consider this practice as trespass, and may instigate police intervention. Although prices for berondol are low per kilo the research notes that women can collect between 40-60 kg per day, so this activity can make a meaningful difference to family income, perhaps explaining its persistence despite the threat of violence or prosecution if discovered. Further issues considering women's work are covered in more detail under SDG 8.

\section{GOAL 6: SECURE AVAILABILITY AND SUSTAINABLE MANAGEMENT OF WATER AND SANITATION FOR ALL}

The metrics of this SDG are clearer than for some of the others: sanitation facilities and access to handwashing with soap clearly relate to the quality of life of citizens, typically an issue of government infrastructure. SDG 6.1.1. covers the availability of clean drinking water, which would usually also be a government obligation except there are some countries in which a significant proportion of drinking water is delivered to the home by the private sector. Other indicators more clearly relate to corporate actions, such as SDG 6.3.1 'the share of wastewater safely treated', SDG 6.4.1 'changes in water-use efficiency over time' and SDG 6.4.2 'rates of freshwater withdrawal relative to the availability of available resources'. The last of these is a clear example of where any attempt to produce credible data must engage multiple stakeholders since it involves co-operation across all parts of a water basin and - potentially- exercising some self-restraint on behalf of some water users.

Private sector actors would need to share in any collective action plan, and improvements in wastewater treatment in production plants would make 
a recognised contribution to the delivery of this goal, even if those gains would be masked by the aggregation of all industries within a country.

Since oil palm flourishes as a crop only in regions with high natural rainfall levels and suitable terrain and soils to retain this water, rates of water withdrawal are not often an issue for this industry. Where expansion of the industry does have serious impact is in the primary processing stage since extracting crude palm oil (CPO) is extremely waterintensive: one tonne of crude palm oil (CPO) output is estimated to generate 2.5 tonnes of palm oil mill effluent (POME). This effluent is a suspension in water of approximately $5 \%$ (by weight) of oil residue and solids and carries a high biochemical oxygen demand (BOD) load which can be extremely damaging to the local ecosystem. Writing of the historical Malaysian experience, Kathuria and Khan (2002) say that as a result of palm oil industry expansion

“by mid-1977, 42 rivers in Malaysia were so severely polluted that freshwater fish could no longer survive in them" (p3993).

It is therefore not surprising that governments in both Malaysia and Indonesia have instigated various pollution caps and licenses to reduce this impact and these costs are part of the normal running costs of mill facilities and included in a corporate profit and loss statement. Changes in practice could therefore reduce running costs.

In his Harvard analysis of why businesses should engage in sustainability, Michael Porter points to 'win-win business opportunities' where efficiency gains can support and endorse changes in business practice. A good example of this comes from a study in Indonesia conducted by Hasanudin et al (2015) focused on the fact that once effluent and waste by-products were examined in more detail they were recognised as potential profit generators.
The early 'treatment' of effluent-leaving it outside in open ponds- was recognised as generating substantial amounts of methane, which could be collected and used to generate electricity, thereby cutting the running costs of the plant. Secondly, the release of POME via land discharge was shown to have a fertilising influence and so partially-treated POME is now returned to the plantations as a liquid feed which has been shown to increase fresh fruit bunch yields (in this study by $+13 \%$ ).

A final indirect influence encouraging wastewater treatment was a consequence of regulatory changes in purchasing markets. The EU initially mandated a $5.75 \%$ target proportion of 'renewable fuels' within the total transport fuel mix under the Renewable Energy Directive of the European Union (Directive 2003/30/EC) although this opportunity has since been restricted. If the land use conversion is ignored (see SDG 13), palm oil is an efficient feedstock for 'renewable energy'. In order to qualify as a desirable biodiesel feedstock in Europe, each feedstock had to show a significant reduction in the life cycle carbon footprint relative to mineral oil sources. Methane gas is a greenhouse gas with an impact of $25 x$ times that of carbon dioxide (Saswattecha et al 2015: 164) and so methane capture technology considerably reduced the carbon footprint of palm oil biodiesel, easing access to the European markets (for a time).

These issues show the interconnectedness of many stakeholders for a single goal in terms of sources of influence for corporate behaviour, but also highlights the greater drive for action provided by the potential for commercial gains to add to philanthropic ideals.

GOAL 7: SECURE ACCESS TO AFFORDABLE, RELIABLE, SUSTAINABLE AND MODERN ENERGY FOR ALL

The metrics for this goal focus on delivery of generated electricity and investments in new technologies rather than transport fuels, the segment most relevant for palm oil. These are only incorporated into metric 7.2.1'renewable energy 
share in the total final energy consumption' of a country and form a small part of national energy production which may include solar, wind and nuclear production. However the transport industry is a vital enabler of logistics in all countries and the 'form factor' advantage of biodiesel in allowing the installed base of vans, trucks and cars to continue in operation is no small consideration: while electric or fuel cell cars require a major change in automobile design, the ability to add a liquid which flows into existing fuel tanks and can use the existing fuel delivery system infrastructure is commercially compelling. Palm oil biodiesel is easily mixed with mineral diesel in car and truck engines at low concentrations (5\% or B5) with no significant impact on engine performance in warmer countries (although it tends to thicken in very cold climates). Although technically higher percentages could be used, the insurance industry has a key influence in restricting its usage, claiming that higher percentages may invalidate motor insurance cover (until longer term impacts on engine health can be assessed).

SDG 13 includes a more detailed discussion on palm oil's carbon footprint, but some additional comments on palm oil's suitability as a biofuel are worth making. Fry and Fitton (2013) note that the demand for biodiesel to replace fossil fuels particularly favours the oil palm, as there is an $89 \%$ oil content for the fruit drupes and only $11 \%$ meal content, so there's little wastage, particularly when compared to soybeans. Concerns over rates of land conversion per unit of oil output also favour palm oil as the trees produce a fivefold oil yield per hectare advantage over oilseed grains (Fry and Fitton 2013, Basiron 2007). As a result, barring the edible oil price spike in 2008 and occasional meddling of governments in export tax rates, palm oil is often the cheapest biodiesel feedstock available on an FOB basis (i.e. ex-shipping costs to the purchasing market). Of the by-products that do come from palm oil processing, several can be used to improve renewable energy inputs: methane capture from POME (already mentioned), and the burning of empty fruit bunches and palm kernel residues in furnaces. Ensuring full recycling of plant material in this way allows palm oil producers to remain important players in modern energy markets. However, the gains to a country under this SDG from increasing biodiesel usage are in clear tension with the assessments of the total carbon impact of palm oil expansion including land use change on climate change, covered in SDG 13.

\section{GOAL 8: SUSTAINED, INCLUSIVE AND SUSTAINABLE ECONOMIC GROWTH, FULL AND PRODUCTIVE EMPLOYMENT AND DECENT WORK FOR ALL}

Sadly, the 'sustainable' economic growth in this headline relates to the robustness, rather than the quality, of that growth: at the indicator level only classic GDP growth gets a mention. A few indicators ask for material intensity measures for that GDP growth - although in a national aggregate figure its not clear how useful this can be. It is in the considerations of acceptable working conditions that this goal offers clear articulation with the private sector, notably through wage rates, occupational injuries, freedom of association and collective bargaining. This SDG benefits from external reference to standards already established under the International Labour Organisation (ILO).

This goal does include several metrics which help to recognise female wage rates (SDG 8.5.1) and the incidence of women's informal agricultural engagement (SDG 8.3.1) which are often assumed to be part of SDG 5. The informality of women's work may have consequences for working conditions. Bissonnette (2013) also notes that women's opportunities on plantations are limited to 'light maintenance tasks' such as spraying and fertilising the plantations but often without any safety equipment in the face of highly toxic chemicals. Payment is typically per diem so women rarely feature on the estate company's pay list and are thus ineligible for employee benefits. White and White (2012), investigated working conditions for women, noting that safety equipment had to be paid for by the worker themselves : 
'spraying work paid $\$ 2.60$ per day but this was the same as the price for a single cloth mask, which was very heavy to wear in such hot weather which further discouraged safe working conditions.' (p1006).

These health and safety concerns are not exclusive to female employees. Deros et al (2016) conducted a Malaysian study in which they observed that palm fresh fruit bunches are typically handled without ergonomic considerations and as such there is a prevalence of back pain among manual plantation workers. For good quality oil, fruit bruising must be minimised, and processing must take place as soon as possible after harvesting. Access routes and careful handling are therefore key, with trolley transport typical for small-scale collections and lorries used for larger scale aggregations. The lifting and twisting manoeuvres involved in filling these vehicles with heavy fruit bunches (weighing $40 \mathrm{~kg}$ each) are extremely repetitive. The field study noted that $81 \%$ of all subjects were aware of correct procedure as a result of training, yet only $17.1 \%$ said they actually used the recommended practices as they were slow and so reduced income which was based entirely on weight of product delivered.

One issue that remains widely ignored throughout the SDGs is that of the status of migrant workers, but acknowledgement of the incidence of occupational injuries under indicator 8.8.1 is one of the very few. However, the wage rate indicator (8.5.1) only requires the statistics to be broken out by gender, age and persons with disabilities. Malaysia brought in labour from other countries for both rubber and palm oil plantations, and Indonesia has tried to migrate domestic inhabitants from overcrowded islands, such as Java, towards land-rich, under-occupied Kalimantan. These migrants have no pre-existing local social ties and no land except for what the migration programme allows, and as a result are even more tied into the agricultural development programmes than the locals. Bessou (2014) maintains that this labour inflow and the slow distribution of smallholding plasma plantations deliberately retains a pool of cheap labour for the estate plantations who are often the sole source of employment in the area. Under such conditions, terms of work can be set entirely to the plantation company's advantage, resulting in adverse incorporation for paid employees to add to the adverse incorporation of smallholder farmers discussed under SDG 2.

As this goal relates to the palm oil supply chain, the primary focus is on local employment policies and the level of wages paid. Terms of employment and job security vary greatly within the plantations. Sinaga (2013) usefully parses the local employment categories in his Indonesian study: 'admin staff' are on monthly pay and have high social status; 'permanent employees' are on daily pay but are formally recognised on the payroll; and two categories of casual labour lack any formal recognition. The first are ' $\mathrm{BHL}$ hires' made directly by the company and the second are unpaid casual workers - friends or family who help to deliver piecework targets for paid members of the workforce (but have no access to revenue recognition themselves). He notes that a minimum wage level exists for those with a less than 12 months working period but "in practice, however, minimum wage is used as a maximum standard in determining the wage level.". The issue of discounts netted against indicated wages appears repeatedly in palm oil ethnographies, as does the precarious nature of employment. Libraswulan (2014), writing in the Asian Journal of Women's Studies records working conditions on an Indonesian plantation thus:

'Budi had signed a contract to work as a driver, but ended up working as a harvester. He lived together in a house with 40 other laborers. The management would lock them in from $10.00 \mathrm{pm}$ to 4.00 a.m. Neither electricity nor toilets were available, so they had to take a leak inside the house. Salty 
fish was given to them for their daily meals and on pay day, they did not receive their salaries because the company deducted all their costs on their labor (sic) such as on transportation, food and accommodation. So they did not receive a salary for up to two years.' ( $p 2)$.

From the fine-tuning of employment categories described it is easy to see how company policies which demand high standards but relate to only full-time employees may differ greatly from the more precarious and exploitative working conditions often noted in NGO campaigns against palm oil. Corporations can choose higher standards in their supply chain- and very many of them do- but in many cases the buyers rely on setting contract terms for their upstream suppliers ('scope 3' to use the Carbon Disclosure Project terminology) which requires some additional form of supervision or verification by either internal audits, or more often audits by third party certification bodies, thus widening the web of stakeholders that are needed to assist to make credible the private sector engagement with delivering the goals.

\section{GOAL 10: REDUCE INEQUALITY WITHIN AND AMONG COUNTRIES}

Several of the metrics for this SDG focus on understanding the type of person living at below average incomes, asking for statistics broken down by age, sex and persons with disabilities. It includes indicators of discrimination or harassment for characteristics prohibited under 'international human rights law' in 10.3.1 which is the only place in the SDGs where freedom of sexual orientation is acknowledged, albeit very indirectly. Most of these issues are in the purview of governments or supra-national regulators, including monitoring of global financial institutions, although there is scope for private sector involvement in managing down declared costs of remittance transfer under 10.c.1. Others relate to relations between nations: enhanced representation of developing countries in global institutions, differential import tariffs for key less- and least-developed nations and increased aid and Foreign Direct Investment.

For the palm oil industry, a relevant touchpoint is covered in 10.b.1's reference to foreign direct investment (FDI) as a source of capital for plantation investment. Investments in new territories with suitable climates for tropical food production have increased significantly since the food price spikes of 2008 when agricultural land became widely recognised as an increasingly scarce resource in the face of growing population pressure. Reported land sales have been extremely large in scale and investors, far from being just the state-owned aggressors noted in the press and NGO literature, have included domestic middle class and urban elites as well as international businesses. Coupled with palm oil's high potential profitability as a biofuel source there has been a lot of NGO criticism that large scale land-grabs may potentially deprive local citizens of food supplies, but the challenge to local sovereignty could be more far-reaching. Cotula's 2013 study 'The Great African Land Grab?' includes the following observation about a proposed palm oil contract in Cameroon:

'A legal analysis of a contract for palm oil operations in Cameroon found that the contract purported to prevail over national law in case of conflict, and that it allowed the company to pay employees according to 'minimum wage scales fixed on the basis of productivity and efficiency criteria...these two provisions taken together could be interpreted as allowing the company to pay employees less than Cameroon's minimum wage..' (p117).

Another important reference to migration issues in SDG 10.7 'to facilitate orderly, safe, regular and responsible migration and mobility of people' has only minimal backup at the metrics level. Indicator 10.7.1 asks only for the share of annual income for a worker absorbed by recruitment costs for that work 
and 10.7.2. only asks if a country has a well-managed migration plan. No specific mention is made of expectations of the quality of working conditions as discussed under SDG8. The demands for migrant labour are at two levels in the supply chain: firstly, the agricultural aspects of the plantation involve seasonal swings in demand for labour required and the second is the need for consistent harvesting and delivery of feedstock to the palm oil mills to ensure commercial utilisation rates.

Pye et al (2012) conducted a biographical study of migrant workers from Indonesia which highlights the precarious status that they have in their new settlements in Malaysia. The destination regime, they say, discourages the permanent settling of migrants, blocks them from citizenship and discourages hybridisation of Malaysian culture (citing Castles 2004). Numbers of immigrants are restricted by permits which specify a country of origin and these permits (and the migrants' passport) remain with the employer during the contract which prevents any transfer to alternative employers unless the migrant is willing to accept 'illegal' status and its accompanying threat of deportation or punishment. No unions with locals are accepted and any children of relationships made by migrants are automatically deemed illegals also. Periodic clearances of illegals have taken place, such as after the financial crisis of 2008. Spatial separation of the plantation dormitories from village settlements further isolate the migrants from integrating into any normal life. Since for the SDGs, a well-planned migration policy is only to be set at the national level, it is unclear whether at the implementation stage there would be any enforcement to counter abuses: this leaves the responsibility for better practice in individual businesses in the realm of voluntary codes.

\section{GOAL 12: SECURE SUSTAINABLE CONSUMPTION AND PRODUCTION PATTERNS}

Goal 12 would appear to be one with the clearest links to improving industrial practice and indeed this does turn out to be the case for quantifying food waste (SDG 12.3) and recycling rates (SDG
12.5). SDG 12.4 endorses international multilateral environmental agreements which specify recognised international standards for hazardous waste management and asks for the share of each treatment available used. There are also several measures of resource intensity requested, such as 12.2.2 (a copy of 8.4.1) 'domestic material consumption, domestic material consumption per capita and domestic material consumption per GDP' and 12.2.1 which is the same information but measured as a proportion of GDP. Governmentdriven initiatives encouraged include sustainable public procurement policies and education on more sustainable lifestyles, the content of which are left up to individual countries. Other issues remain extremely vague, such as metric 12.6.1 'Number of companies publishing sustainability reports' and 12.1.1 'Number of countries with sustainable consumption and production (SCP) national action plans or SCP mainstreamed as a priority or a target into national policies' as very little is said about what such reports should contain.

Many issues relating to a broader concept of sustainability, such as ecosystem damage or social justice are more directly measured under other SDGs but it may be particularly useful here to highlight the fact that definitions of what constitutes sustainable production and consumption- targets set by national governments- may vary greatly for a globalised supply chain. It is therefore up to the buyers to decide which standards should be met along the full extent of their own supply chain. The added complication is that identification of a 'sustainable' product is not possible using chemical sampling techniques: the molecules are substantially indifferent to whether it has been tended and harvested by happy workers or those in abject misery, and where exactly it was grown has little relevance to its final utility unless a conscious social choice makes it so. Ensuring sustainable production or consumption therefore involves some form of labelling capability and a process of checks and validation to make this credible, which gives rise to a whole parallel industry of 'trust' badging to discriminate between batches of previously fungible 
commodities.

From the consumption end, in Western markets, palm oil is not readily identified in the end product to a meaningful degree: its presence is often hidden as a small part of a long ingredients list (as is the case for prepared meals) and only since December 2014 has the EU shifted from allowing the generalist term 'vegetable oil' to mandating the specific plant sources. Badging for certified sustainable palm oil (CSPO), currently endorsed by the Roundtable for Sustainable Palm Oil (RSPO), is very rarely used on products in the region. Perhaps the dubious reputation of the industry is indicated by increasing marketing of products or ranges as 'palm -oil free' such as Iceland Foods recent 'Rang-Tan' advertising campaign (made by Greenpeace). For large corporations the sustainable palm oil policy is often made available at the Head Office corporate brand level, rather than the individual product. In developing markets however, where palm oil is often used as the cooking oil of choice, the CSPO label is sometimes used. The geographical end-user markets may therefore determine the relevant trust authorities to be used.

A study by Boons and Mendoza (2010) analysed the construction of sustainable palm oil by looking at producers in Colombia and buyers in the Netherlands. They note that the choice of application may also differentiate 'appropriate' sustainability considerations: palm oil for food and cosmetic use may benefit from certified organic status as a price differentiator, while that directed for the biofuel industry will not. The large scale of the biofuels market encourages more widespread POME methane capture and other carbon-footprint reducing actions so that the end-product meets the life cycle Cramer criteria for identifying and selecting preferred biofuel feedstocks. However, for food applications buyers are more sensitised to biodiversity concerns, not least due to extensive NGO campaigns by Friends of the Earth, World Wildlife Fund and others. As a result, far from being a uniform commodity 'sustainable palm oil' takes multiple forms and circulates in differentiated product pathways (in line with Douglas and Isherwood's analysis from 1979). This concept of contingent sustainability standards for different buyers makes for particular supply chain complexity.

\section{GOAL 13: TAKE URGENT ACTION TO COMBAT CLIMATE CHANGE AND ITS IMPACTS}

For SDG 13 'climate change' appears to have absorbed most references to natural disaster planning, even though not all such incidences are climate change-related. SDG 13.1.2 requests mortality rates to such events (as does SDG 1.5). Many of the metrics are yes/no in format, such as SDG 13.1.1 (does the country have a national and local disaster reduction strategy); SDG 13.2.1 (does the country have an integrated climate change mitigation strategy) or 13.3 (are there plans to improve education on climate change mitigation measures). However, unlike the sustainability plans in SDG12 there are several references to what such a plan must include within the metric itself.

The remaining metrics focus on mobilisation of finance to mitigate climate change (from donors in SDG 13.a.1 and to recipients in SDG 13.b.1), although oddly, quantification of fossil fuel subsidies is requested under another goal (SDG 12.c.1) and then only as a proportion of GDP which in effect masks the high absolute quantum of these subsidies for more developed economies. Disappointingly there are no metrics relating to data on absolute carbon footprints or management of other greenhouse gases at the national level, perhaps owing to the lack of mature institutions to construct internationally accepted standards for these datapoints. Given the scale of scientific research devoted to the topic through the IPCC and other industry bodies in constructing sector standards it is possible that private sector companies who already submit to the Carbon Disclosure Project request are in this instance, ahead of the game.

The caveat against this optimism comes from the difficulty of tracking emissions far upstream of the reporting company. While Scopes 1 and 2 of the CDP disclosure relate to the operations of 
the business itself, scope 3 relates to upstream operations, many of which are not owned but are merely contractual partners and thus require checks and verification that contract standards are being observed.

A second caveat which attaches more to the commodity itself is that of the calculation of 'lifecycle assessments' in carbon evaluations. As mentioned in SDG 7 the immediate carbon gain from switching to biofuels is offset by attaching land use change carbon values which mean that palm oil of the same quality from location A may carry a very different carbon value to some from location B. Danielsen et al's 2009 study emphasises that land clearance is a huge carbon release, particularly if the prior ground cover is removed by burning. To give their comparison, clearing mature primary forest yields 225 tonnes of carbon per hectare, while clearing grassland yields only 5 tonnes/ hectare. Re-cultivating oil palm trees on the same land sequesters approximately 50 tonnes of carbon/ hectare over 30 years, so converting grassland into oil palm plantations achieves a net carbon capture for the lifetime of the plantation but removing primary forest does not. The same authors suggest that for peat forest conversion the carbon stock replacement period can be as high as 600 years.

Even the basis for the land use change impact to be amortised over the production from the plantation is dubious: technically the carbon release has happened even prior to the first year's production and as Cherubini (2012) comments the past land use clearance becomes a 'sunk cost' for future users. So on what basis is the historic clearance of forested land to remain an albatross hanging from the neck of all subsequent usage of that land and what would be a reasonable statute of limitations on the land use change impact: the 30-40 year duration of the first trees or for every subsequent planting as well? This may explain why statistics for carbon footprinting this product vary so widely, and it is often the buyers who get to decide upon which version to use, as was the case for the EU decision to allocate standardised land use change carbon charges to determine the acceptability of feedstock sources in the second iteration of biofuel regulations.

In a synthesis of these two elements - provenance and chemistry - into a life cycle analysis Bessou et al (2011) investigated a pilot application of RSPO GHG calculation methodologies for 9 RSPO members in a variety of countries and terrains. This suggested an average release of 1.67 tonnes of $\mathrm{CO}_{2}$ equivalent per tonne of extracted Crude Palm Oil (CPO) produced across all areas. The key variables in this calculation were prior land use, the choice of clearance amortisation period, oil yields achieved and soil type (particularly peatland). Two other greenhouse gases in the palm oil life cycle have a disproportionate impact. Methane released from primary processing plants has a GHG impact $25 x$ that of carbon dioxide and nitrous oxide $\left(\mathrm{N}_{2} \mathrm{O}\right)$ released by fertiliser over-application has a massive 298x impact (EPA 2005), so even small shifts in these gases can distort relative attributed carbon values. As a result waste methane due to mill processing also made a meaningful impact on the calculation as did the high levels of nitrogen-based fertiliser application needed to sustain high yields. The authors note that carbon stock metrics are still not robust enough to provide common ground for action but the attempt at calculation does highlight the key levers for improvement, starting with banning peatland development, a controversial issue, particularly for Indonesia which has an estimated $21 \mathrm{~m}$ hectares of undeveloped peatland available.

The climate change metrics therefore necessitate close supervision not only of the mill processing but also of the agricultural practices undertaken by each supplying smallholder and plantation. To fulfil this goal it seems that a massive expansion in environmental auditors will be required, whose fees will inevitably be added to costs of supply. 
GOAL 15: PROTECT, RESTORE AND PROMOTE SUSTAINABLE USE OF TERRESTRIAL ECOSYSTEMS, SUSTAINABLY MANAGED FORESTS, COMBAT DESERTIFICATION AND HOLD AND REVERSE LAND DEGRADATION AND HAULED BIODIVERSITY LOSS

While quantifying the scale of areas that need to be protected would seem a sensible approach, several metrics for this SDG instead involve proportions of national land use: 15.1.1 'forest area as a proportion of total land area', 15.1.2 'proportion of important sites for terrestrial and freshwater biodiversity that are covered by protected areas, by ecosystem type', 15.3.1 'proportion of land that is degraded over total land area' and 15.c.1 'proportion of traded wildlife that was poached or illicitly trafficked'. This obscures the aggregate global need for absolute levels of forest and biodiversity protection which demands more of some countries than others, such as those with large areas of tropical rainforest such as Indonesia and Malaysia.

However, this is also the SDG in which outreach to prior institutional standards is most apparent, such as 15.9.1 which incorporates national targets established in accordance with Aichi Biodiversity target 2 of the 'Strategic Plan for Biodiversity' established in October 2010 by the Conference of the Parties. Under this commitment each country has -it claims-laid out an action plan adapted to its own biological resources. A second such indicator is 15.5.1 in which aims to 'protect and prevent the extinction of threatened species' uses the categorisation set out by the 'Red List', which is a science-based determination of which species are threatened maintained by The International Union for the Conservation of Nature and Natural Resources (IUCN). Finally, 15.4 which proposes the conservation of mountain ecosystems using the 'Mountain Green Cover Index' metric produced by the Mountain Partnership Secretariat hosted by the Food and Agriculture Organisation (FAO) of the United Nations. The links to pre-established metricsupervising institutions which are science-based makes this SDG much more robustly rooted in data than the still-negotiated climate-change estimated statistics noted in SDG 13.

For the palm oil industry there are many academic studies which show species depletion in plantations: by way of a sample Danielsen et al (2009) note significant reductions in flora, invertebrates and vertebrates in their collation of multiple studies carried out by others in either Malaysia or Indonesia. More positively, Ancrenaz' 2015 study of Orang-utan observations in and around plantations showed that mature plantations allowed co-existence with the species provided that specified patches of mixed forest were maintained in the local area. Boons and Mendoza (2010) note that in Colombian palm oil plantations these protected areas, locally knows as 'morichales', also supported pollinating insects crucial to the successful delivery of the palm oil fruits, so the concept of ecological islands or corridors of undeveloped land are widely seen as a desirable inclusion in plantation planning. If combined with protected riparian areas they may also protect local waterways from excessive pollution and soil erosion, helping to preserve freshwater life. However, the science-based identification of the relevant areas to be protected can be expensive and take time to be identified accurately. New concepts of citizen science are being trialled as a way to leverage local population expertise and interest, much of which has been enabled by the rapid expansion of GPS location technology and mobile telephony. Such environmental audits are another layer of expense for producers and their customers but given the sensitivity of end-consumers in mature markets to biological damage the reputational risk of not attending to these issues is high.

GOAL 16: PROMOTE PEACEFUL AND INCLUSIVE SOCIETIES FOR SUSTAINABLE DEVELOPMENT, PROVIDE ACCESS TO JUSTICE FOR ALL, AND BUILD EFFECTIVE, ACCOUNTABLE AND INCLUSIVE INSTITUTIONS AT ALL LEVELS

While SDG 1 focuses on poverty in the sense of the citizens' capacity to consume goods necessary for their survival, this SDG collects data more 
akin to a wider concept of 'prosperity', including personal safety (16.1.4), particularly from homicide (16.1.1 and 16.1.2) or rape (16.1.3 and 16.2.3). The incidence of national human rights institutions (established according to the Paris principles) is to be recorded (16 a 1) and recognising the share of the population which feels a sense of discrimination or harassment under any of the recognised human rights categories is covered by 16.b.1. Metrics 16.5.1 and 16.5 .2 ask for an indication of public sector or corporate requests for bribes (which is unlikely to produce statistics with a high degree of accuracy) some of which may relate to land use change in terms of titling or permit issuance, as previously mentioned.

By asking for higher standards of behaviour in the workplace, private sector companies may help alter normative expectations, but it must be noted that this is still only in the realm of voluntary behaviour change. From academic literature Rist (2010) notes:

'Commonly companies failed to meet the terms of community agreements, particularly in the development of schools and clinics or the provision of technical assistance in plantation management. Local officials have a vested interest in ensuring that oil palm development goes ahead; taxes on agricultural products and enhanced district authority over agricultural land, as well as bribes and financial support during electoral campaigning make oil palm development highly desirable to them...When problems arise at a later stage the officials have moved on to another official position and are no longer accountable' (p1017).

Thus the the private sector needs just as much auditing and verification of its behaviour if claims for corporate responsibility are to be credible. 


\section{CONCLUSIONS}

While critical of the metrics, this study is not intended to disparage the SDGs as a high-level roadmap for driving change and delivering greater prosperity for the population. Indeed by setting out a widely-consulted consensus for desired changes in behaviour, the framework offers an important 'boundary object' around which a wide variety of stakeholders can coalesce in order to drive progress (Nicolini et al 2012), even if they bring widely differing capabilities and jargon to the table. The very incidence of these stated ambitions -even by headline- raises reputational risk for a business perceived as ignoring these issues in their supply chain. However, the SDGs as presented fall short of a map of how to get there, even for governments, since many of the statistics requested are only descriptive in nature and retrospective. How to achieve these changes and the prioritisation of goals in tension is left open for negotiation between a wide variety of stakeholders with no over-arching supra-national enforcement capability.

From the outset, the need for private sector engagement has been wrapped up in a narrative of 'responsibility' and 'bringing energy' to tackle these challenges. At a much more fundamental level however it is clear that many of these issues require considerable investment and that governments alone cannot mobilise the scale of finance required. Co-opting the private sector into making their contribution is vital and- on occasion- the re-design of business processes can generate commercial as well as wider benefits as expressed in Porter's 'win-win' model. Where progress may grind to a halt is where there is no extra economic benefit to be had in return for changes in behaviour, and here legislation may be required, but it will be a brave government who raises costs for business in isolation from its economic competitors, given the rapidity of capital flows towards higher returns.

A second observation is that where the SDGs build on issues recognised over long periods of time, reference to established international institutional norms for standards and metrics can be helpful in providing guidance for the private sector over the changes that should be made. Such issues include the international code for human rights, those developed by the International Labour Organisation and several of the ecological reference points named in SDG 15. Where these institutional buttresses do not yet exist - most notably for climate change but also in water system management- the potential for prompt action is constrained by the need to define terms, units and methodologies between stakeholders. In the case of climate change the vision shown by the Carbon Disclosure Project ( a third sector initiative) shows that new institutional actors may be needed to streamline these processes and offer standards on an international basis separate from slower-moving intergovernmental agreements.

In part the potential for the private sector to engage with the SDGs is also limited by mismatch of boundaries for engagement: supply chains for many products are international while the unit of data collection and the recognition of change will be collected on a nation-state basis. Thus the attribution of credit for companies taking voluntary actions towards the goals involves an appeal to an international audience on the basis of meeting revised social norms, which are themselves partly identified and publicised by publicity around the 
SDGs. Further, as commercial economic entities, the private sector engages predominantly with working age members of the population, rather than the very young, the unemployable and the elderly who remain in the purview of their governments.

The study also highlights that any corporate claims to meet SDG ambitions need to be flanked by parallel certifying and auditing initiatives, such as voluntary codes and transparent disclosure of the resource footprint of their operations (both for inputs and outputs). The cost of these credibility badges will have to be incorporated into the final products or services sold, yet may only prove commercially desirable to suitably sensitised -usually wealthy- consumers. It is therefore possible that implementing the SDGs will prove inflationary: not just in terms of higher prices for natural resources highlighted as becoming more scarce as the population grows, but also in the additional layer of audit costs required to avoid accusations of corporate greenwashing. Voluntary codes may provide a beacon for how business could be done differently, but it is likely that not all commercially driven businesses will make these investments. Formal legal backup and enforcement of higher standards by governments may be necessary to bring new industry practices up to a scale at which progress is significant. At present governments are asking for private sector commitment to help deliver the goals: at some point in the future they may demand it. This inter-regnum of accumulated voluntary codes may be temporary but those who participate now will be better prepared and have more resilient business strategies in place to face the future. 


\section{BIBLIOGRAPHY}

Ancrenaz M., Oram F., Ambu L., Lackman I., Ahmad E., Elahan H., Kler H., Abram N.K. and Meijard E. (2014) 'Of Pongo, palms and perceptions; a multidisciplinary assessment of Bornean orangutans Pongo pygmaeus in an oil palm context' Oryx 49 (3) pp465-472

Azhar B. Saadun N., Puan C.L. Kamarudin N., Aziz N., Nurhidayu S. and Fischer J. (2015) 'Promoting landscape heterogeneity to improve the biodiversity benefits of certified palm oil production: Evidence from Peninsular Malaysia' Global Ecology and Conservation 3 pp553-561

Basiron Y (2007) 'Palm oil production though sustainable plantations' European Journal of Lipid Science 109 p289-295

Bessou C, Chase L, Henson I, Abdul-Manan A, Mila y canals L, Agus F, Sharma M and Chin M (2104) 'Pilot application of Palm GHG, the Roundtable on Sustainable Palm Oil greenhouse gas calculator for oil palm products' Journal of Cleaner Production 73 p136-145

Bissonnette, J. (2013) 'Development through Large-scale Oil Palm Agribusiness Schemes: Representations of possibilities and the Experience of Limits in West Kalimantan', Sojourn: Journal of Social Issues in Southeast Asia 28 (3) pp485-511

Boons F and Mendoza A (2010) 'Constructing Sustainable Palm Oil: how actors define sustainability' Journal of Cleaner Production 18 p1686-1695
Cahyadi E.R. and Waibel H. (2013) 'Is contract farming in the Indonesian Oil Palm industry Propoor?' Journal of SouthEast Asian Economies 30 (1) pp62-76

Carlson K.M., Curran L.M.,Ratnasari D., Pittman A.M., Soares-Filho B.S., Asner G.P., Trigg S.N., Gaveau D.A., Lawrence D and Rodrigues H.O. (2012) 'Committed carbon emissions, deforestation, and community land conversion from oil palm plantation expansion in West Kalimantan, Indonesia' Proceedings of the national Academy of Sciences of the United States of America 109 (19) pp7559-7564

Castles S (2004) 'The myth of controllability of difference. Labour migration, transnational communities and state strategies in the Asia-Pacific region' in Yeoh BSA and Willis K [eds] 'Perspectives on trans-nationalism in the Asia-Pacific' pp16-36 Routledge, London

Cherubini F, Guest G and Stromman A (2012) 'Application of probability distributions to the modelling of biogenic $\mathrm{CO}_{2}$ fluxes in life cycle assessment' GCB Bioenergy 4 (6) p784-798

Corley R.H.V. and Tinker P.B. (2003) The Oil Palm (4th Edition) Blackwell Science , Oxford

Cotula L. (2013) 'The Great African Land Grab'

Danielsen F, Beukema H, Burgess N D, Parish F, Bruhl CA, Donald PF, Murdiyarso D, Phalan B, Reijnders L, Struebig M and Fitzherbert E 'Biofuel Plantations on Forested Lands: Double Jeopardy for Biodiversity and Climate' Conservation Biology 23 (2) pp348-358 
Darshini D., Dwivedi P. and Glenk K (2013)

'Capturing stakeholder's views on oil palm-based biofuel and biomass utilisation in Malaysia' Energy policy 62 pp1128-1137

Dauvergne P. and Nevill K. (2010) 'Forests, food and fuel in the tropics: the uneven social and ecological consequences of the emerging political economy of biofuels' The Journal of Peasant Studies 37 (4) pp631-660

Deros B.M., Ali M.H., Mohamad D. and Darius DDII (2016) 'Ergonomic Risk Assessment on Oil Palm Industry Workers' Iran Journal of Public Health Vol 45 Suppl 1 p44-51

Douglas, M. and Isherwood, B (1979) The World of Goods. Towards an anthropology of consumption Basic Books : New York

Edris A. (1999) 'Agrarian Change and Rural Women: The Malaysian Experience' Asian Journal of Women's Studies 5 (4) pp28-56

EPA (2005) 'Methane and Nitrous Oxide Emissions from Natural Sources' Environmental Protection Agency, Washington DC.

Euler M., Krishna V., Schwarze S., Siregar H., and Qaim M. (2017) 'Oil Palm Adoption, Household Welfare, and Nutrition Among Smallholder Farmers in Indonesia' World Development ${ }^{* * *}$ in press ${ }^{* *}$

Fargione J, Hill J, Tilman D Polasky S and Hawthorne P (2008) 'Land clearing and the biofuel carbon debt' Science 319 p1235-1238

Feintrenie, L. 2010. Why do Farmers Prefer Oil Palm? Lesson Learnt from Bungo District, Indonesia. SmallScale Forestry 9: 379-396

Fry J and Fitton C (2013) 'The Importance of the Global Oils and Fats Supply and the Role that Palm Oil plays in Meeting the Demand for Oils and Fats Worldwide' Journal of the American College of Nutrition 29 sup 3 245S-252S
Gustafsson, F. 2005. 'The Visible Palm. Market Failures, Industrial Policy and the Malaysian Palm Oil Industry'. Lund Studies in Economic History 44 Lund University.

Gan P.Y. and Li Z.D. (2014) 'Econometric study on Malaysia's palm oil position in the world market to 2035' Renewable and Sustainable Energy Reviews 39 pp740-747

Hamilton-Hart N ( 2014) 'Multilevel (mis)governance of palm oil production' Australian Journal of international Affairs 69 (2) p164-184

Hasanudin U, Sugiharto R, Haryanto A, Setiadi T and Fujie K (2015) 'Palm oil mill effluent treatment and utilization to ensure the sustainability of oil palm industries' Water Science and Technology 727 1089-1095

Hoffmann M.P., Donough C.R., Cook S.E., Fisher M.J., Lim Y.L., Cock J., Kam S.P., Moharanaj S.N., Indrasuara K., Tittinutchanon P. and Oberthur T. (2017) 'Yield gap analysis in oil palm: Framework development and application in commercial operations in Southeast Asia' Agricultural Systems 151 pp12-19

Jaung W., Putzel L, Bull G.Q., Kozak R. and Markum ? (2016) 'Certification of forest watershed services: A $Q$ methodology analysis of opportunities and challenges in Lombok, Indonesia' Ecosystem Services 22 pp51-59

Kathuria V. and Khan N.A. (2002) 'Environmental Compliance versus Growth: Lessons from Malaysia's Regulations on Palm Oil Mills' Economic and Political Weekly 37 (39) pp3993-3999

Koh, L.P., J. Miettinen, S.C. Liew and J. Ghazoul, 2011. 'Remotely sensed evidence of tropical peatland conversion to oil palm' Proceedings of the National Academy of Sciences of the USA, 108 (12): 5127-5132

Lam MK, Tan KT, Lee K T, Mohamed AR (2009) 'Malaysian Palm oil: Surviving the food vs fuel dispute for a sustainable future' Renewable and Sustainable Energy Review 13 p1456-1464 
Laurance W.F., Koh L.P., Butler R., Sodhi N.S., Bradshaw C.J.A., Neidel J.D., Consunji H. and Vega J.V. (2010) 'Improving the Performance of the Roundtable on Sustainable Palm Oil for Nature Conservation', Conservation Biology 24 (2) pp377381

Libraswulan R.S. (2014) 'Palm Oil Plantations: Nowhere to Escape' Asian Journal of Women's Studies 20 (4) pp122-133 (note: all online versions available lack relevant page numbering for citation)

Ludin N.A., Bakri M.A.M., Kamaruddin N., Sopian K., Deraman M.S., Hamid N.H., Asim N. and Othman M.Y. (2014) 'Malaysian oil palm plantation sector: exploiting renewable energy toward sustainability production' Journal of Cleaner production 65 pp9-15

McCarthy, J.F. and, R.A. Cramb (2009) Policy narratives, landholder engagement, and oil palm expansion on the Malaysian and Indonesian frontiers. The Geographical Journal 175(2): 112-123.

McCarthy, J. (2010) Processes of inclusion and adverse incorporation: oil palm and agrarian change in Sumatra, Indonesia. The Journal of Peasant Studies 37(4): 821- 850.

Moore H.L. (2015) Global Prosperity and Sustainable Development Goals Journal of international Development 27 p801-815

Mukherjee,I. and Sovacool, B. (2014) 'Palm oil based biofuels and sustainability in southeast Asia: A review of Indonesia, Malaysia and Thailand' Renewable and Sustainable Energy reviews 37 pp112

Nesadurai H (2013) 'Food Security, the palm oil-land conflict nexus, and sustainability: a governance role for a private multi-stakeholder regime like the RSPO?' The Pacific Review 26 (5) 505-529

Nicolini D, Mengis J and Swan J (2012)

'Understanding the Role of Objects in Cross-

Disciplinary Collaboration' Organization Science 23

(3) p612-629
Othman J. (2003) 'Linking Agricultural Trade, Land Demand and Environmental Externalities : Case of Oil Palm in South East Asia', ASEAN Economic Bulletin 20 (3) pp244-255

Pichler M. (2013) 'People, planet \& Profit': Consumer-Oriented Hegemony and Power Relations in Palm Oil and Agrofuel Certification', Journal of Environment and Development 22 (4) pp370-390

Potter, L. and S. Badcock (2004) 'Cash crop smallholders, capitalism and adat: Studies in Riau Province, Indonesia', Asia Pacific Viewpoint, 45(3), 341-356.

Potter, L. 2009. Oil palm and resistance in West Kalimantan, Indonesia, in: D. Caouette, and S. Turner (eds.) Agrarian Angst and Rural Resistance in Contemporary Southeast Asia, Routledge.

Potter L. 2009. Resource Periphery, corridor, heartland: Contesting land use in the Kalimantan/ Malaysia borderlands. Asia Pacific Viewpoint 50(1): 88-106.

Potter, L. 2010. Kalimantan in the firing line: a note on the effects of the global financial crisis, Bulletin of Indonesian Economic Studies, 46(1): 99 - 109.

Purseglove J.W. (1972) Tropical Crops: Monocotyledons. Harlow : Longman

Putrasari Y., Praptijanto A., Santoso W.B. and Lim O. (2016) 'Resources, policy, and research activities of biofuel in Indonesia: A review' Energy Reports 2 pp237-245

Pye O, Daud R, Harmono Y and Tatat (2012) 'Precarious Lives: Transnational biographies of migrant oil palm workers' Asia Pacific Viewpoint 53 (3) p330-342

Pye O. and Bhattacharya J. Eds (2013) The Palm Oil Controversy in Southeast Asia: A Transnational Perspective, Singapore Institute of Southeast Asian studies, Singapore 
Rifin A (2010) 'The Effect of Export Tax on Indonesia's Crude Palm oil (CPO) Export Competitiveness', ASEAN Economic Bulletin 27 (2) p173-184

Riggs R.A., Sayer J., Margules C., Boedhihartono A.K., Langston J.D., Sutanto H. (2016) 'Forest tenure and conflict in Indonesia: Contested rights in Rempek Village, Lombok' Land Use Policy 57 pp241-249

Rist L., Feintrenie, L. and Levang P. (2010) 'The livelihood impacts of oil palm: smallholders in Indonesia', Biodivers Conserv 19 pp1009-1024

Sairin, S. 1996. The Appeal of Plantation Labour: Economic Imperatives and Cultural Considerations among Javanese Workers in North Sumatra.

Sojourn. Journal of Social Issues in Southeast Asia 11(1): 1-23.

Saswattecha K, Kroeze C, Jawjit W and Hein L (2015) 'Assessing the environmental impact of palm oil produced in Thailand' Journal of Cleaner production 100 p150-169

Siegmann, K.A. 2003. "Just our husbands' helpers": Gendered labour market segmentation in large estates in North Sumatra, Indonesia. Islamabad: Sustainable Development Policy Institute.

Sinaga H., (20130 'Employment and income of Workers on Indonesian Oil Palm Plantations: Food Crisis at the Micro Level' Future of Food: Journal on Food, Agriculture and Society 1 (2) pp64-78

Stone R. (2007) 'Can Palm Oil Plantations Come Clean?' Science 317 (5844) pp1491

Tata H, van Noorwijk M, Ruysschaert D, Mulia R, Rahayu S, Mulyoutami E, Widayati A, Ekadinata A, Zen R, Darsoyo A, Oktaviani R and Dewi S (2014) 'Will funding to Reduce Emissions from Deforestation and (forest) Degradation (REDD+) stop conversion of peat swamps to oil palm in orangutan habitat in Tripa in Aceh, Indonesia?' Mitigation and Adaptive Strategy in Global Change 19 p693-713
Teuscher M., Vorlaufer M., Wollni M., Brose U. ,Mulyani Y. and Clough Y. (2015) 'Trade-offs between bird diversity and abundance, yields and revenue in smallholder oil palm plantations in Sumatra, Indonesia' Biological Conservation 186 pp306-318

Tsujino R., Yumoto T., Kitamura S., Djamaluddin I. and Darnaedi D (2016) 'History of forest loss and degradation in Indonesia' Land Use Policy 57 pp335-347

UN (2015) Resolution 70/1 'Transforming Our World: the 2030 Agenda for Sustainable Development' accessible online at https://sustainabledevelopment. un.org/post2015/transformingourworld/publication

World Integrated Trade Statistics found on : https:// wits.worldbank.org/countrysnapshot/en/

White J. and White B. (2012) 'Gendered experiences of dispossession: oil palm expansion in a Dayak Hibun community in West Kalimantan' The Journal of Peasant Studies 39 (3-4) pp995-1016

World Growth (2010) 'Palm oil and Food Security: The Impediment of Land Supply', World Growth, Virginia USA

Yusoff S (2006) 'Renewable Energy from Palm Oil innovation on effective utilization of waste' Journal of Cleaner Production 14 p87-93 
Research at the Institute for Global Prosperity at UCL aims to generate new insights about sustainable and inclusive prosperity and provide new models for developing and interpreting evidence.

Underlying our research is a rethinking of what we mean by prosperity. Prosperity must mean enabling people to flourish in ways beyond financial growth -and doing so equitably and sustainably, for humankind and the planet. We work with businesses, NGOs and citizens to produce interdisciplinary methodologies and problem-focused research.

For more information about our wide range of current projects and our innovative Masters and PhD programmes please see: www.ucl.ac.uk/bartlett/igp/ 